\title{
Solusi Terhadap Problematika Pendidikan Dalam Pembelajaran di Pesantren Pada Era Abad ke-21
}

\author{
Dheanda Abshorina Arifiah \\ Universitas Islam Negeri Sunan Kalijaga Yogyakarta \\ dheanda.abshorina18@gmail.com
}

\begin{abstract}
Abstrak: Pesantren dapat disebut juga lembaga pendidikan non-formal. Pendidikan dalam pesantren juga semestinya perlu mengikuti zaman agar nantinya lulusan dari pesantren juga dapat bersaing dengan masyarakat umum lainnya. Salah satu langkah agar pendidikan dalam pesantren mengikuti zaman ialah dengan memperbarui metode pembelajaran lama menjadi metode pembelajran yang terbaru yang up to date. Hal ini agar para santri juga dapat menyerap ilmu dengan sempurna. Penelitian ini menggunakan pendekatan kualitatif dengan jenis penelitian kepustakaan. Sumber data penelitian ini berasal dari buku, jurnal dan artikel ilmiah terkait tantangan yang dihadapi pesantren di era globalisasi. Analisis data dalam penelitian ini menggunakan teknologi content analysis yaitu pengolahan data melalui pemilahan tersendiri. Diskusikan beberapa pemikiran atau gagasan pendidik, kemudian uraikan, diskusikan dan kritiklah. Hasil dari penelitian ini ialah Dengan berkembangnya teknologi, metode dalam pembelajaranpun seharusnya dapat mengikuti zaman. Selain itu, aplikasi pembelajaranpun semakin canggih, sudah semestinya sebagai seorang pendidik harus kreatif dalam memanfaatkan sekitar kita.
\end{abstract}

Kata Kunci: Solusi; Problematika; Pendidikan Pesantren.

Abstract: Pesantren is a non-formal educational institution. Education in pesantren should also need to keep up with the times so that later graduates from pesantren can also compete with other general public. One of the steps for education in pesantren to keep up with the times is to update the old learning methods into the latest up-to-date learning methods. This is so that the students can also absorb knowledge perfectly. This research uses a qualitative approach with the type of library research. The data sources of this research come from books and journals and scientific articles related to the challenges of Islamic boarding schools in the era of globalization, while the data analysis in this study uses content analysis techniques, namely data processing by separate sorting. related to the discussion of some ideas or thoughts of educational figures which are then described, discussed, and criticized. The result of this research is that with the development of technology, methods in learning should be able to keep up with the times. In addition, learning applications are increasingly sophisticated, as an educator, we must be creative in utilizing our surroundings.

Keywords: Solutions; Problems; Islamic Boarding School Education.

\section{Pendahuluan}

Pendidikan pada hakikatnya bukan saja soal transformasi pengetahuan. Bukan juga hanya soal proses pembelajaran yang membuat manusia mampu memahami dan mengetahui ilmu. Apalagi hanya soal sederet angka prestasi siswa yang terekam dalam catatan formal laporan kemajuan mereka atas penguasaan ilmu tertentu. Lebih dari itu, pendidikan merupakan proses pendewasaan sikap dan perilaku, sehingga orang yang terlibat dalam proses pendidikan itu mampu hidup bermasyarakat dengan segala bentuk dinamikanya. Karena itu, orang yang terdidik sejatinya adalah orang yang mampu mengetahui, mampu berbuat sesuai dengan pengetahuan yang dimilikinya, mampu 
menentukan pilihan hidupnya secara bertanggung jawab, dan mampu hidup bersama dalam masyarakat. ${ }^{1}$

Perkembangan teknologi ini juga berpengaruh di bidang pendidikan. Dahulu sumber referensi ilmu hanya terpaku pada buku cetak saja. Akan tetapi pada masa sekarang peserta didik di semua jenjang dapat menambah pengetahuan dan wawasan melalui internet. Akses-akses untuk mendapatkan referensi secara online juga sangat banyak dan mudah. Bahkan seperti yang kita alami di masa pandemi ini, semua satuan pendidikan mau tidak mau memberikan fasilitas pembelajaran jarak jauh. Dengan adanya internet, guru dan peserta didik dapat berkomunikasi secara virtual tanpa harus bertemu secara langsung. Pendidikan yang condong pada penguasaan pengetahuan semata akan menciptakan manusia yang cerdas tapi tidak berkarakter baik. Akibatnya jika proses pendidikan yang dilakukan dalam pesantren tidak dapat mengikuti perkembangan zaman, maka kualitas alumni ini kurang mampu bersaing dengan masyarakat lain khususnya di dunia kerja.

Pesantren sebagai lembaga sudah hadir selama ratusan tahun yang menawarkan program pendidikan berbasis keagamaan Islam. Selain pendidikan kurikulum nasional, para santri yang menghuni suatu pesantren juga diajar pendidikan Agama Islam secara intensif, dakwah, dan sebagainya di pondok pesantren tersebut. ${ }^{2}$ Pentingnya metode dalam kegiatan belajar mengajar juga dapat mempengaruhi kualitas pendidikan tersebut. Karena jika pendidik menggunakan metode yang tepat maka materi yang didapat peserta didik juga akan lebih maksimal. Namun pada kenyataanya, umumnya pesantren masih menggunakan metode pengajaran yang terbilang kuno yakni hanya dengan metode ceramah saja terutama pada pesantren salaf.

Pondok pesantren sebagai salah satu bentuk pendidikan Islam diharapkan dapat terus berperan dalam menciptakan sumber daya manusia (SDM) yang unggul di tengah derasnya arus globalisasi. Karena zaman dapat berubah dengan cepat dan penuh kejutan. Jika tidak segera diantisipasi, maka kemungkinan besar pesantren akan terpinggirkan karena sistem pendidikan di pesantren yang mengalami ketertinggalan dalam kemajuan budaya global.

Akan tetapi, permasalahan terhadap pesantren akan tetap ada di abad ke-21 ini jika pesantren tidak mau mengikuti zaman. Beberapa kalangan masih memandang sebelah mata pesantren sebagai lembaga yang cenderung menentang arus perkembangan zaman. Padahal sesungguhnya anggapan tersebut tak sepenuhnya demikian.

Berdasarkan penelitian terdahulu, maka beberapa artikel yang membahas terkait problematika pendidikan pesantren yakni sebagai berikut:

Pertama, artikel berjudul "Problematika Pesantren Sebagai Lembaga Pendidikan Islam diIndonesia" yang ditulis oleh Alaika M. Bagus Kurnia Ps dalam Jurnal Pendidikan Islam, Vol. 10 No. 10, tahun 2019. Ini membahas Pendidikan agam Islam harus membimbing peserta didiknya dalam perkembangan mereka, baik secara fisik maupun secra spiritual terhadap pembentukan kepribadian siswa itu sendiri, utamanya yang didasarkan pada hukum Islam. Namun seiring berjalannya waktu, pendidikan Islam tidak lagi semaju dahulu, pendidikan Islam saat ini, telah mengalami banyak kemunduran karena beberapa faktor. Pesantren sebagai lembaga pendidikan Islam juga tidak dapat menghindari berbagai permasalahan yang muncul di era global. Sebagai lembaga pendidikan Islam tradisional di Indonesia, Pesantren mempunyai peran penting dalam melindungi dan mengembangkan pengetahuan Islam. Selain itu, pesantren telah berperan dalam membentuk karakter umat Islam Indonesia. Pada masa Orde Baru, pesantren bersaing dengan sekolah-sekolah yang diakui pemerintah. Selain itu, pola kehidupan manusia

\footnotetext{
${ }^{1}$ Jamal Ma'mur Asmani, Pendidikan berbasis keunggulan lokal, (Yogyakarta: Diva Press, 2015) hlm. 21.

${ }^{2}$ Ahmad Farhan, Pendidikan di Pesantren, (Jakarta; Azza Grafika, 2018) hlm. 22
} 
modern juga mempengaruhi eksistensi pesantren sebagai lembaga pendidikan Islam tradisional. Untuk mempertahankan eksistensinya, Pesantren melakukan beberapa perubahan yang dianggap perlu, dengan tetap mempertahankan tradisi masa lalu. ${ }^{3}$

Kedua, artikel berjudul "Pesantren Terpadu Sebagai Solusi Problematika Pendidikan Agama Islam Di Era Globalisasi" yang di tulis oleh Vialinda Siswati dalam jurnal Tawazun: Jurnal Pendidikan Islam, Vol. 10 No. 10, tahun 2019. Ini membahas pendidikan agama Islam mempunyai banyak tantangan diera globalisasi. Kemajuan sains, teknologi, informasi dan transformasi telah berdampak pada tatanan masyarakat. Pendidikan sebagai gerbang utama dalam membina akhlak manusia mempunyai tugas yang amat berat. Pesantren yang merupakan salah satu lembaga pendidikan Islam memiliki tantangan yang berat pula. Oleh karena itu untuk senantiasa tetap eksis sebagai bangsa yang menjujung nilai-nilai moral dan kemanusiaan yang tinggi, maka pengembangan pesantren juga harus merespon beberapa kemajuan-kemajuan yang ada dengan cara mengembangkan ilmu-ilmu modern dengan tetap mempertahankan nilai-nilai lama yang sudah baik. Pengembangan pesantren merupakan harapan besar bagi seluruh masyarakat modern yang sudah geram terhadap perilaku globalisasi yang telah melibas tatanan sosial yang manusiawi. Pendidikan pesantren merupakan jawaban dari segala ketidak puasan masyarakat modern. Dengan pola keterpaduan sistem dan pembelajaran di pesantren, diharapkan mampu mengatasi problematika dikotomi keilmuan selama ini. Mengintegrasikan kembali antara agama dan sains merupakan titik balik kebangkitan umat Islam untuk memainkan perannya sebagai umat yang mempunyai peradaban yang tinggi dalam bidang keilmuan. ${ }^{4}$

Ketiga, artikel yang berjudul "Tantangan Dan Solusi Bagi Madrasah Dan Pesantren Dalam Menghadapi Era Globalisasi” yang ditulis Ariski Nuril Indah dalam Jurnal Tarbiyah wa Ta'lim, Vol. 5 no. 1, tahun 2018 yang membahas salah satu lembaga pendidikan Islam di Indonesia adalah Madrasah dan pesantren. Peran dari pendidikan Islam di zaman sekarang ini adalah harus siap menghadapi perkembangan dan kemajuan teknologi yang sebagian besar berasal dari negara-negara asing. Madrasah dan pesantren harus dimutakhirkan dan direformasi untuk menciptakan generasi yang tangguh, yaitu generasi yang berilmu luas dan mampu mengembangkan ilmu yang bersumber dari Al-Qur'an dan Hadist. Hal ini dapat menciptakan generasi yang tidak hanya berhasil dalam urusan agama, tetapi juga dapat menghadapi kemajuan ilmu pengetahuan dan teknologi di era globalisasi. tulisan ini bertujuan untuk menggali tantangan dan solusi yang dihadapi pendidikan agama Islam di madrasah dan ponpes di abad ke--21, di masa ini, yang dapat dilakukan madrasah dan ponpes untuk meningkatkan pendidikan Islam adalah dengan mengidentifikasi tantangan yang dihadapi madrasah dan ponpes dan memahami bagaimana solusi pendidikan Islam dapat mencapai tujuan pendidikan yang diinginkan. ${ }^{5}$

Keempat, artiket berjudul "Problematika dan Tantangan Pendidikan Pondok Pesantren di Era Informasi" yang ditulis oleh Suparno dalam Jurnal Fikroh Vol. 11 No. 1 tahun 2018 membahas Di era globalisasi dengan arus informasi yang begitu pesat, pendidikan Islam menghadapi berbagai permasalahan, seperti: relasi kuasa dan positioning pendidikan Islam, profesionalisme tenaga pendidik, masalah kurikulum, infrastruktur yang tidak memadai, serta metode komunikasi yang seimbang.

Tantangan dan permasalahan yang dihadapi oleh pondok pesantren yakni problematika akademik yang meliputi: terjadi pada kurangnya guru profesional yang

${ }^{3}$ Kurnia Ps, Alaika M. Bagus, Problematika Pesantren Sebagai Lembaga Pendidikan Islam di Indonesia, dalam Jurnal Tawazun: Jurnal Pendidikan Islam, Vol. 10 No. 10, 2019.

${ }^{4}$ Vialinda Siswati, Pesantren Terpadu Sebagai Solusi Problematika Pendidikan Agama Islam Di Era Globalisasi, dalam Jurnal Pendidikan Islam Vol. 2, no. 2, 2018.

5 Ariski Nuril Indah, Tantangan dan Solusi bagi Madrasah Dan Pesantren Dalam Menghadapi Era Globalisasi, dalam Jurnal Tarbiyah Wa Ta'lim, Vol. 5 no. 1, 2018. 
berkualitas, metode pengajaran yang masih tradisional dan jenisnya tidak banyak, kebijakan kurikulum yang terus berubah. Selain itu, problematika yang ditemukan di pesatren juga terjadi pada non-akademiknya, problematika-problematika tersebut meliputi: fasilitas pendidikan yang tidak mencukupi, dan dana pesantren tidak mencukupi. ${ }^{6}$

Kelima, artikel berjudul "Problematika Pendidikan Pesantren Dalam Meningkatkan Insan Akademis Berkualitas Di Era Global Multikultural" yang ditulis oleh Buyung Surahman dalam Jurnal Wahana Akademika Vol. 5 No. 2 Tahun 2018 membahas di era globalisasi, pendidikan pesantren menghadapi kendala dalam meningkatkan bakat akademik. Di pesantren, tren global dapat menimbulkan gejala anti-moral, seperti halnya gaya hidup Barat, bahkan sangat mempengaruhi moralitas, akhlak, dan perilaku manusia. Dalam hal ini dampak terhadap kehidupan jasmani dan rohani umat sangat besar, oleh karena itu pendidikan pondok pesantren menghadapi berbagai tantangan bagi warga masyarakat untuk mengembangkan model pendidikan di era globalisasi, antara lain masalah kelembagaan, masalah sumber daya manusia, dan pengembangan kurikulum. Oleh karena itu, di zaman modern, dalam rangka meningkatkan kualitas bakat akademik, pesantren mengalami kesulitan dalam menggali semua sumber daya yang dimilikinya, karena dipengaruhi oleh pendidikan Pesantren dan mendominasi masalah, masalah sumber daya manusia, dan Barat yang kuat. Dan pengaruh imperialisasi informasi, serta arus budaya yang mengglobal, dapat menimbulkan gejala paradoks atau anti moral. Menghadapi masalah ini, sudah saatnya pesantren mencurahkan seluruh sumber daya, upaya dan kemampuannya untuk terus berinovasi dan menemukan hal-hal baru yang dapat membantu kehidupan mereka menjadi lebih baik. Jika pesantren tidak menggali semua kemampuannya, maka akan tertinggal oleh zaman yang terus berkembang. ${ }^{7}$

\section{Metode Penelitian}

Metode pendekatan yang digunakan dalam penelitian ini ialah menggunakan metode pendekatan kualitatif dengan jenis penelitian kepustakaan atau disebut dengan Library Reseach. Sumber data penelitian ini berasal dari buku, jurnal dan artikel ilmiah yang terkait dengan tantangan yang dihadapi pesantren di era abad ke-21. Analisis data dalam penelitian ini menggunakan teknologi Content Analysis, yaitu mengklasifikasikan atau mengkelompokkan data secara terpisah terkait pembahasan beberapa ide atau gagasan tokoh pendidikan, kemudian mendeskripsikan, mendiskusikan dan mengkritisinya. Selain itu, klasifikasikan data serupa dan analisis konten secara kritis untuk mendapatkan hasil yang spesifik dan memadai ${ }^{8}$

\section{Hasil dan Pembahasan}

\section{A. Makna Problematika Pendidikan Islam}

Masalah menurut bahasa yakni "problem", yang berarti masalah, masalah atau kebingungan. Artinya juga ada masalah yaitu ketidakpastian. Adapun masalah pendidikan mengacu pada permasalahan atau permasalahan yang dihadapi oleh dunia pendidikan khususnya Indonesia. Indonesia adalah salah satu negara dengan penduduk muslim terbesar di Asia. Padahal pendidikan Islam bukanlah muatan utama pendidikan nasional. Pendidikan Islam selalu dianggap sekunder atau marjinal dalam sistem pendidikan nasional. Padahal,

\footnotetext{
${ }^{6}$ Suparno, Problematika dan Tantangan Pendidikan Pondok Pesantren di Era Informasi, dalam Jurnal Fikroh, Vol. 11, No. 1, tahun 2018.

7 Buyung Surahman, Problematika Pendidikan Pesantren Dalam Meningkatkan Insan Akademis Berkualitas Di Era Global Multikultural, dalam Jurnal Wahana Akademika, Vol. 5, No. 2, Tahun 2018.

${ }^{8}$ Dedy Mulyana, Metodologi Penelitian Kualitatif, (Bandung: PT. Remaja Rosdakarya, 2017), hlm. 157.
} 
pendidikan apapun, termasuk pendidikan nasional dan pendidikan Islam, pada hakikatnya membangun harkat dan kemanusiaan, menjadikan mereka khalifah

Pendidikan Islam memiliki kedudukan dalam sistem pendidikan yang terbagi menjadi tiga bagian. Pertama, sebagai sebuah lembaga, pendidikan Islam secara jelas mengakui keberadaan lembaga pendidikan Islam. Kedua, sebagai mata pelajaran, pendidikan Islam mengakui bahwa pendidikan agama merupakan salah satu mata pelajaran yang wajib diajarkan dari sekolah dasar hingga perguruan tinggi. Ketiga, pendidikan Islam sebagai nilai-nilai ajaran Islam dalam sistem pendidikan ${ }^{9}$

\section{B. Sejarah pesantren}

Pondok-pondok pesantren sudah hadir sejak zaman kolonialisme, karena pada dasarnya pesantren dulu didirikan sebagai bentuk penentangan kolonialisme itu sendiri. Banyak tokoh agama Islam ternama di zaman itu, seperti KH. Hasyim Asyari, KH. Zaenal Mustopa dan KH. Ahmad Dahlan turut berkontribusi terhadap perjuangan kemerdekaan Indonesia. Tidak lama setelah negara Indonesia mengumumkan kemerdekaanya, pendidikan agama di semua jenis sekolah mendapatkan perhatian serius dari pemerintah. Hal inilah yang mendasari pemerintah Orde Lama untuk merumuskan UU No. 4 Tahun 1950 yang berisi tentang Pendidikan Agama. Undang-undang tersebut menyatakan bahwa orang tua memiliki kehendak agar anaknya mengikuti pendidikan tersebut atau tidak, serta pelaksanaan pendidikan agama sekolah negeri yang diatur sesuai dengan kebijakan milik Menteri Pendidikan Pengajaran \& Kebudayaan dan Menteri Agama. ${ }^{10}$

Tepatnya pada tanggal 3 Januari tahun 1946, Departemen Agama mulai berdiri. Departemen tersebut aktif memperjuangkan pendidikan Islam di Indonesia, bahkan departemen tersebut memiliki unit khusus untuk mengurus hal ini yaitu Bagian Pendidikan Agama. Pembinaan Pondok Pesantren dilakukan oleh sebuah Subdit di wilayah Direktorat Pembinaan Perguruan Agama Islam yang berdasarkan Keputusan Menteri Agama No. 6 Tahun 1979. Sementara itu pada zaman Orde Baru, Perkembangan pendidikan pesantren mengalami stagnansi karena pemerintah yang berkuasa waktu itu memiliki kebijakan yang netral secara agama. ${ }^{11}$

Perkembangan pendidikan pesantren baru mengalami kebangkitan ketika Era Reformasi, karena pada waktu itu pondok pesantren telah diakui sebagai institusi resmi dari sistem pendidikan nasional yang dibukukan pada Undang-Undang Sisdiknas atau Sistem Pendidikan Nasional. Melalui pengakuan pemerintah tersebut, legalitas pondok pesantren sebagai salah satu lembaga pendidikan resmi sah termasuk memiliki kesetaraan hak dan kewajiban dengan lembaga pendidikan formal lainnya. Pendidikan Pesantren mengalami perkembangan yang amat signifikan sehingga Subdit Pondok Pesantren telah berkembang menjadi Direktorat Pendidikan Keagamaan dan Pondok Pesantren berdasarkan keputusan Menteri Agama Nomor 1 Tahun 2001. Lalu pada tahun 2006 badan tersebut berevolusi kembali menjadi Direktorat Pendidikan Diniyah dan Pondok Pesantren atas dasar Peraturan Menteri Agama RI No. 3 Tahun 2006. ${ }^{12}$

\section{Metode Pengajaran Dalam Pesantren}

Pondok Pesantren sebagai salah satu lembaga pendidikan memiliki ciri tersendiri dalam kegiatan belajar mengajarnya, termasuk dalam metode yang digunakannya. Banyak sekali metode-metode yang diterapkan di pondok pesantren. Dari sekian banyak metode itu, secara

${ }^{9}$ Kurnia Ps, Alaika M. Bagus. "Problematika Pesantren Sebagai Lembaga Pendidikan Islam di Indonesia, dalam Jurnal Tawazun: Jurnal Pendidikan Islam, Vol. 10 No. 10, 2019.

${ }^{10}$ Moh. Cholil, Relevansi Sistem Pendidikan Pesantren Tradinional Dalam Era Modernisasi, dalam Jurnal Tarbawi, Vol. 03 No. 1, 2017.

${ }^{11}$ Riyadi, Bilik-bilik Islam: renungan dari Lorong kusam pesantren, (Surabaya: IMTIYAZ, 2012), hlm.

12 Akmalia suci, Pembaharuan Pesantrentradisional, (Bangdung: PT. Ramaja Rosdakarya, 2017), hlm. 
garis besar dapat dikelompokan menjadi dua bagian, yaitu metode pembelajaran tradisional (asli pesantren) dan metode pembelajaran yang bersifat pembaharuan. ${ }^{13}$

Pondok pesantren tradisional atau pondok pesantren salaf masih tetap memepertahankan pengajaran kitab-kitab klasikal sebagai inti pendidikannya dengan metode pembelajaran tradisional. Metode pembelajaran tradisional meliputi:

a. Metode Sorogan yakni metode pengajaran dengan cara menghadap guru seorang demi seorang dengan membawa kitab yang akan dipelajari.

b. $\quad$ Metode Weton atau Bandongan dimana para santri mengikuti pelajaran dengan duduk di sekeliling Kyai yang menerangkan pelajaran secara kuliah, santri menyimak kitab masing-masing dan membuat catatan padanya

c. Metode Halaqah yakni kegiatan belajar mengajar yang dilakukan oleh seorang ustadz atau kiai dengan cara duduk di hadapan santrinya sambil membacakan materi kitab. Para santri yang mengikuti pembelajaran ini duduk dalam bentuk setengah lingkaran dan bersaf-saf. ${ }^{14}$

Sedangkan dalam pondok pesantren modern, metode pembelajaran sudah menggunakan metode yang lebih variatif dengan metode pembelajran yang sudah diperbarui dengan mengikuti era globalisasi. Adapun metode pembaharuan meliputi:

a. Metode Hiwar yakni percakapan silih berganti antara dua pihak atau lebih melalui tanya jawab mengenai suatu topik yang mengarah pada suatu tujuan. Percakapan ini bisa dialog langsung dan melibatkan kedua belah pihak secara aktif, atau bisa juga yang aktif hanya salah satu pihak saja, sedang pihak lain hanya merespon dengan segenap perasaan, penghayatan dan kepribadiannya.

b. Metode Bahtsul Masa'il, yakni metode pembelajaran yang sistemnya lebih mirip dengan metode diskusi atau seminar.

c. Metode Fathul Kutub yakni Kegiatan pembelajaran santri pada kyai/ustadz dengan mempelajari materi pada kitab tertentu, dilakukan secara terus menerus oleh sekelompok santri dalam tenggang waktu tertentu. Biasanya berlangsung selama setengah bulan, dua puluh hari atau kadang-kadang sebulan penuh di bulan Ramadhan, tergantung pada kitab yang dikaji dalam pondok pesantren tersebut.

d. Metode Muhawarah suatu kegiatan wajib pesantren yang isinya tentang pelatihan berbahasa Arab kepada para santri selama mereka tinggal di pondok tersebut.

e. Metode Demonstrasi, yakni metode pembelajaran yang di bimbingan Kyai/ustadz dan diperagakan satu atau sekelompok santri dengan memperagakan (menunjukkan) keterampilan melakukan ibadah tertentu.

f. Metode Mudzakarah yakni pertemuan ilmiah yang diselenggarakan oleh para santri dan dipimpin oleh kyai untuk mendiskusikan suatu masalah, tujuannya agar para santri dapat terlatih dalam menggunakan kitab-kitab yang ada untuk menyelesaikan masalah tersebut. ${ }^{15}$

\section{Solusi Problematika Pendidikan Pesantren Di Era Globalisasi}

Metode dalam pembelajaran di pesantren menjadi salah satu permasalahan yang penting, karna metode pengajaran di pesantren yang terkesan ketinggalan zaman. Metode pembelajaran menjadi sangat penting apabila dapat divariasi karena jika metode pembelajaran hanya monoton seperti itu saja, maka akibatnya peserta didik akan merasa bosan dan materi yang didapatpun kurang maksimal. Seperti halnya dalam pesantren yang sebagian besar hanya menggunakan metode ceramah.

Metode pembelajaran bandongan sudah sanggat pas digunakan dipesantren dan sesuai dengm ajaran Islam tentang Istima' (Menyimak). Al-Quran telah menyebutkan bahwa mengingat adalah aktivitas yang dilakukan oleh manusia ketika mempelajani atau memahami sesuatu selain melihat. Seperti dalam Q.S. Al A'raf ayat 204:

\footnotetext{
${ }^{13}$ Riyadi, Bilik-Bilik Islam: Renungan Dari Lorong Kusam Pesantren,..., hlm. 30

${ }^{14}$ Abu Yasid, Pendidikan Pesantren Menuju Pendidikan Islam Transformatif, (Yogyakarta: IRCISOD, 2018), hlm. 10

${ }^{15}$ Akmalia suci, Pembaharuan Pesantrentradisional,...hlm. 67.
} 


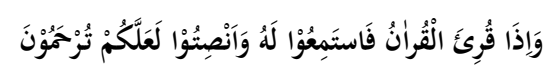

"Dan apabila dibacakam Al-Qur'an maka dengarkanlah baik- baik, dan perhatikanlah dengan tenang agar kamu mendapat rahmat" (QS Al-A'raf: 204').

Ayat tersebut mengandung maksud bahwa ketika ayat-ayat Al-Quran dibacakan hendaknya kita harus mendengarkan dengan baik dan memerhatikan apa yang terkandung dalam setiap bacaan ayat-ayat Allah. Dengan demikian, kita bisa mengambil pelajaran dari apa yang kita dengar. Dalam perspektif Islam aktivitas belajar dengan mendeng haruslah dilakukan untuk mendengarkan sesuatu yang bermanfaat, dan larangan mendengar sesuattu yang tidak bermanfaat. Namun dizaman sekrang ini, mobilitas semakin tinggi perkembangan teknologi semakin pesat, metode bandongan ini perlu adamya inovasi baru yaitu dengan bandongan virtual, guru atau ustad tidak harus bertatap muka langsung dalam satu forum melainkan bisa menggunakan aplikasi google meet, zoom, atau pun aplikasi media lainnya dalam melakukan pembelajaran. sama halnya dengan sistem sorogan yang menyetor bacaan kitab yang sudah Yang sudah dikaji sebelumnya untuk disetorkan kepada gurunya.

Sistem sorogan ini juga sudah sesuai dengan yang diajaran oleh Al-Qur'an yaitu mengenai Qira'ah (Membaca). Membaca merupakan perintah pertama kepada Nabi Muhammad SAW yang disampaikan melalui malaikat Jibril. Ini artinya penghargaan Islam sangat tinggi terhadap pengetahuan. Kata Iqra yang terdapat pada surat Al-'Alaq ayat 1 terambil dari kata qara'a, yang arti asalnya menghimpun. Kata "menghimpun" mempunyai banyak variasi, yaitu menyampaikan, meneliti, mendalami, menelaah, mengetahui ciri-ciri sesuatu, dan sebagainya.

Perintah pertama untuk membaca ini tidak ditentukan objek bacaannya, hal ini menunjukkan bahwa kita diperintahkan untuk membaca segala sesuatu dan bersifat umum, baik membaca ayatayat Qauliyah (sumber yang tertulis) maupun ayat-ayat Kauniyah (seperti fenomena alam, membaca diri sendiri). Akan tetapi, dalam membaca, menelaah, harus atas nama Allah. Artinya, aktivitas ini dilakukan dalam rangka mengantarkan pelakunya kepda Allah, ikhlas dalam mendekatkan diri kepada Allah.

Dalam sistem sorogan murid membacakan apa yang sudah ia pelajari dihadapan gurunya, inovasi yang bisa dilakukan sama halnya dalam inovasi bandongan yaitu dengan sorogan virtual, guru dan murid tidak ada batasan ruang dan waktu.

\section{Kesimpulan dan Saran}

Dari hasil uraian diatas, maka dapat ditarik kesimpulannya bahwa metode pembelajran sangat berpengaruh dalam aktifitas belajar mengajar di pesantren. Agar pesantren tidak ketinggalan zaman, maka harus dilakukan pembaharuan dalam pembelajaran, seperti dalam Metode prembelajaran yang sudah sangat bervariatif dan mengikuti zaman.Dengan berkembangnya teknologi, metode dalam pembelajaranpun seharusnya dapat mengikuti zaman. Selain itu, aplikasi pembelajaranpun semakin canggih, sudah semestinya sebagai seorang pendidik harus kreatif dalam memanfaatkan yang ada di sekitar kita. Seperti pada metode sorogan dan bondongan dalam pembelajaran yang bisa dilakukan melalui aplikasi-aplikasi cahggih zaman sekarang atau dengan kata lain, pesantren sapat mengkolaborasikan antara metode pembelajaran klasik dengan metode pembelajaran modern yang ada sehingga guru dan murid tidak dibatasan oleh ruang dan waktu. 


\section{Daftar Pustaka}

Asmani, Ma'mur, Jamal, 2015, Pendidikan berbasis keunggulan lokal, Yogyakarta: Diva Press.

Cholil, Moh. 2017, Relevansi Sistem Pendidikan Pesantren Tradinional Dalam Era Modernisasi, dalam Jurnal Tarbawi, Vol. 03 No. 1.

Farhan, Ahmad, 2018, Pendidikan di Pesantren, Jakarta; Azza Grafika.

Indah, Nuril, Ariski, 2018, Tantangan dan Solusi bagi Madrasah Dan Pesantren Dalam Menghadapi Era Globalisasi, dalam Jurnal Tarbiyah wa Ta'lim, Vol. 5 no. 1.

M. Bagus, Alaika, Kurnia, 2019, Problematika Pesantren Sebagai Lembaga Pendidikan Islam di Indonesia, dalam Jurnal Tawazun: Jurnal Pendidikan Islam, Vol. 10 No. 10.

Riyadi, 2012, Bilik-Bilik Islam: Renungan Dari Lorong Kusam Pesantren, Surabaya: IMTIYAZ.

Siswati, Vialinda, 2018, Pesantren Terpadu Sebagai Solusi Problematika Pendidikan Agama Islam Di Era Globalisasi, dalam Jurnal Pendidikan Islam Vol. 2, no. 2.

suci, Akmalia, 2017, Pembaharuan Pesantrentradisional, Bangsung: Rosdakarya.

Suparno, Problematika dan Tantangan Pendidikan Pondok Pesantren di Era Informasi, dalam Jurnal Fikroh, Vol. 11, No. 1, tahun 2018.

Surahman, Buyung, 2018, .Problematika Pendidikan Pesantren Dalam Meningkatkan Insan Akademis Berkualitas Di Era Global Multikultural, dalam Jurnal Wahana Akademika, Vol. 5, No. 2.

Yasid, Abu, 2018, Pendidikan Pesantren Menuju Pendidikan Islam Transformatif, Yogyakarta: IRCISOD. 